\title{
Biologists seek havens for species at risk
}

Rex Dalton, San Diego

The survival of threatened species can be substantially improved by creating critical-habitat sanctuaries, where human activities are tightly restricted, says a survey conducted by a US environmental group.

The establishment of such habitats - which is permitted under the 1973 Endangered Species Act - has been a bone of contention between scientists and federal officials for years. Environmentalists have repeatedly tried to use the act to create habitat sanctuaries, whereas the government has argued that such habitats are of little proven value in saving endangered plants or animals.

But a report released on 6 October by the Center for Biological Diversity in Tucson, Arizona, which is involved in several lawsuits to create habitats, says that species recovery is twice as likely to occur in a critical-habitat sanctuary as it is elsewhere. The study is based on an analysis of recently released data, covering 1998-2001 and some 1,300 threatened or endangered species, from the US Fish and Wildlife Service (FWS).

"These findings are very important for the future of endangered and threatened species and are strong support that designation of critical habitat is fundamental for recovery of these species," says conservation biologist Phil Hedrick of Arizona State and unsuccessfully angled to rewrite sections of the Endanon critical habitats. And at least

If a sanctuary is designated as
University in Tempe, who reviewed the report at the centre's request.

A spokesman for the FWS said that the agency had not seen the report, and could not comment on its contents. But he pointed to a FWS position paper from May which states that critical habitats are of "little conservation benefit to species". Active efforts at conservation are more likely to improve survival than prohibiting activities in habitat sanctuaries, FWS officials say.

The Center for Biological Diversity has charged that the Bush administration was sitting on data released in June for more than two years because they conflicted with the administration's publicly stated view. But the FWS denies withholding the data, saying the failure to release the material was an oversight.

In Congress, Republicans have repeatedly gered Species Act, including that two measures to alter the act are expected to come before Congress next year.

There were only a handful of critical-habitat designations until 1997. But now there are about 435 US critical habitats, covering 38 million acres and 542 species. A further 350 habitat projects are in the works, with about 60 scheduled for completion in the next year.

egged fro

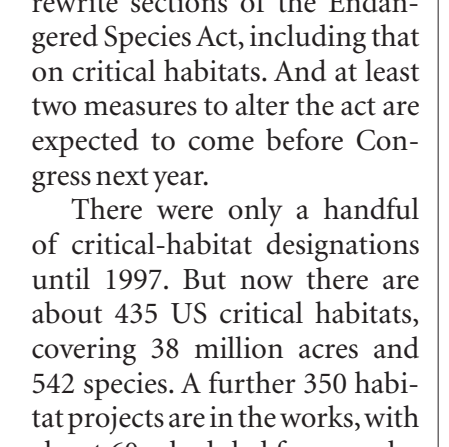
a critical habitat, any federal agency planning
actions related to that area must consult with the FWS on potential impacts. The consultations often lead to controls on activities such as logging, mining and road-building.

Kieran Suckling, the centre's executive director, says that the Bush administration "is starving the FWS budget to slow the protection of critical habitats" ordered by judges. The federal government budgeted $\$ 9$ million this year for creating critical habitats. In the past, the FWS has recommended spending up to $\$ 20$ million a year for six years to create habitats already designated as critical.

The centre's report shows that protecting critical habitats is the best way "to move from species-to-species conservation to real ecosystem protection", says Suckling.

www.sw-center.org

\section{Standards-lab staff up in arms over military link}

Jim Giles, London

The contract to run Britain's National Physical Laboratory (NPL) is up for grabs and scientists there are warily eyeing the prospect that the nation's main standards and measurement laboratory could fall under the auspices of a contractor that specializes in military technology.

QinetiQ, which was spun off from the Defence Evaluation and Research Agency in 2001 to run some of Britain's weaponsdevelopment labs, is one of three contenders to run the NPL when its operating contract is renewed in six months' time.

The NPL, which is based in Teddington near London, had its operations contracted out in 1995 to Serco, a services company that runs everything from sports centres to government computer contracts. But Serco's contract runs out in April 2004, and the Department of Trade and Industry (DTI) has invited bids from companies to run the lab until 2014. QinetiQ, Serco and Scientific Generics, a Cambridge-based consultancy, are all bidding for the contract.

Serco already has some defence interests, but trade unions at the NPL say they find QinetiQ's military focus incompatible with the lab's civilian tradition. "Lots of scientists at the NPL made a conscious choice not to go into defence research," says Fiona Sloman, who represents more than half of the 600 staff at the laboratory for the union Prospect. "They would be concerned about QinetiQ taking over," she adds.

Government officials say that whoever wins the contract will have to pursue the same research agenda, drawn up by the laboratory and the DTI.

But laboratory staff say they are worried that Qinetiq's involvement might deter researchers from joining the lab. "I have big problems with defence companies," says one physicist who joined NPL in part because it

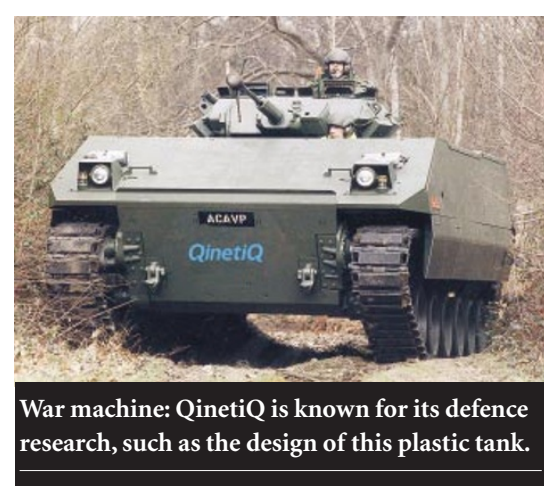

was an applied lab that did not have links to weapons research.

In early November, the DTI is expected to announce which of the three applicants it will choose as its preferred bidder, with whom it will then enter detailed contract negotiations.

www.npl.co.uk 